\title{
Localism Principle in the Formulation of Indonesian Regulations on Pornography
}

\author{
Zulkifli Rahmat ${ }^{1, a)}$ \\ ${ }^{1}$ Universitas Airlangga, Surabaya, Indonesia \\ a) author correspondence: zulkifli.rahmat-2019@fisip.unair.ac.id
}

DOI: https://doi.org/10.18196/jkm.122045

Article Info

Article history: Received 31 Aug 2020

Revised 6 Nov 2020

Accepted 23 Nov 2020

\section{ABSTRACT}

The Law on Pornography is perceived as not reflecting the nationality, the archipelago values, and legal certainty. However, the officials who formulated this policy were deemed to have failed in establishing a clear definition of pornography, which later contributed to the high ambiguity and legal uncertainty of the bill, now an Act. The analysis carried out in this writing focuses on the use of the principle of localism in the preparation of regulations of Law Number 44 of 2008 on Pornography. The approach method used in this qualitative research was the analytical description approach. The formulation of regulations in Indonesia must reflect the principles of protection, humanity, nationality, kinship, recollection as part of the archipelago, unity in diversity, justice, equality before law and government, order and legal certainty and/or balance, harmony, and conformity. The localism principle requires clear and mutually agreed interpretation, it would be useful in policymaking and policy analysis. Surely, the aim is to formulate a policy that contains clear and consistent evaluative and substantive standards. This research showed that the law on pornography, were born as a result of the localism principle not being used as a guideline at the beginning of its formulation.

Keywords: Ambiguity; Localism; Legal Uncertainty; Multiculturalistic Nation; Pornography

\begin{abstract}
ABSTRAK
Undang-undang Pornografi tidak mencerminkan muatan kebangsaan, kenusantaraan, dan kepastian hukum. Pejabat merupakan pihak yang merumuskan kebijakan ini dinilai gagal dalam menetapkan definisi yang jelas tentang pornografi dan telah berkontribusi pada tingginya ambiguitas juga ketidakpastian hukum. Analisis yang dilakukan pada penulisan ini berfokus pada penggunaan prinsip lokalisme yang digunakan dalam penyusunan regulasi pornografi Undang-Undang Nomor 44 Tahun 2008. Metode pendekatan yang digunakan adalah metode pendekatan diskripsi analisis dengan jenis penelitian kualitatif. Penyusunan regulasi di Indonesia seharusnya mencerminkan asas pengayoman, kemanusiaan, kebangsaan, kekeluargaan, kenusantaraan, bhineka tunggal ika, keadilan, kesamaan kedudukan dalam hukum dan pemerintah, ketertiban dan kepastian hukum dan/atau keseimbangan, keserasian dan keselarasan. Prinsip lokalisme juga menjadi penting dan berguna dalam pembuatan kebijakan dan analisis kebijakan yang diharuskan memiliki interpretasi yang jelas dan disepakati bersama sehingga mengandung standar evaluative dan substantive yang jelas dan konsisten di dalamnya. Penelitian ini menunjukkan bahwa Undang-undang Pornografi lahir dengan prinsip lokalisme yang tidak dijadikan pedoman pada awal perumusannya.
\end{abstract}

Keywords: Ambiguitas; Lokalisme; Ketidakpastian Hukum; Multikulturalistik; Pornografi 


\section{INTRODUCTION}

Limiting the production, distribution, and use of pornographic content had long been the aim for Indonesian government in drafting regulations regarding pornography. Starting with President Habibie's administration era in 1999, discussions on the Law on Pornography began until it ended on the ratification of Law Number 44 of 2008 on Pornography on October 30, 2008. However, it turned out that the nine-year long worth of struggle did not guarantee a smooth enactment of the Act.

In a multicultural country, a formulation of a policy that is expected to apply broadly surely must consider all the diversity that exists. The principle to consideration should abide from the beginning of the preparation all the way to the post-ratification socialization and implementation. As yet, Law Number 44 of 2008 on Pornography continues to reap its pros and cons, from its formulation until its post-ratification (Kompas 2008a). Many considered this regulation as a policy that actually ignores the diversity existing in Indonesian society.

Pros and cons discussion that occurred even in the drafting process of the Act was quite a complicated matter, since the bill straightaway touched certain issues prone to relativity and subjectivity. The issues meant here are the way an individual behaves, dress, and express themselves. The problem lies in how precarious it is to judge one's behavior fairly with a single orderly scale regarding the diverse values from various cultures, the local language, race, ethnicity, religion, and belief. On the other hand, this law is also considered to have a high abstraction level to be interpreted and even very likely to eliminate the cultures and customs of the Indonesian people caused by perspective differences (Kompas 2008b).

Multiple interpretations of a policy would much-less have an impact on the implementation process of the Act. In Law Number 44 of 2008 on Pornography, multiple interpretations will further impact the high level of ambiguity and legal uncertainty in its implementation. Moreover, this unclear and ambiguous definition lies in the basic points of this law contained in the General Provisions. This is what initially interested the researcher to discuss further about the regulation (Mustika 2016).

This research is based on the use of the principle of localism used in the formulation of Law Number 44 of 2008 on Pornography. The formulation of Law Number 44 of 2008 on Pornography fails to form a common interpretation of this rule from diverse Indonesian societies. Apart from the high level of multiple interpretations, several establishments for the formation of the Laws and Regulations in Indonesia have also been violated at the stage of the formulation of the pornography law. The principle of localism is also neglected, even though this principle is one of the basic principles of formulating a communication policy (Napoli 2001), which is important in a communication policy to meet the needs and interests of the whole community. This research also takes the example of pornography laws in the United States and Turkey as a comparison.

\section{METHODS}

This type of research was a literature review, which is related to the library data method or research where the object of research is extracted through a variety of library information, such as books, encyclopedias, scientific journals, newspapers, magazines, and documents (Sukmadinata 2009). Primary and secondary data in this research were collected through a literature review of official documents in the form of laws and regulations, decisions of legal institutions, opinions of experts, books and results of conducted studies as well as their various responses, opinions from various observers, and opinions from layers of society found in mass media coverage relating to the essential problem of the law's content or material. Literature review or literature research is research that critically examines or reviews the knowledge, ideas, or findings contained in the body of academic-oriented literature and formulates theoretical and methodological combinations for certain topics (Cooper 1989).

The focus of library research is to find various theories, laws, propositions, principles, or ideas that are used to analyze and solve the research questions formulated. Descriptive analysis process is carried out for regular decomposition of the data that has been obtained, then given an understanding and explanation so that it can be applied properly by the reader. Literature review is a critical and indepth evaluation of previous research (Torraco 2005). A literature review does not only mean reading literature, but more towards an in-depth and critical evaluation of previous research on a research topic, and then summarizing, analyzing, and synthesizing its content and presenting it. A good literature review is one that evaluates the quality and new findings of a scientific paper. 


\section{RESULT AND DISCUSSION}

Localism can be interpreted as 'prioritizing local regards'. In the political context, localism can usually be seen in, for example, support for local production and consumption of goods, local control from the government, and promotion of local history, local culture, and local identity. In other words, in localism, politics see the importance of maintaining regional autonomy in addition to following decisions determined by the central government. Localism in the context of communication policymaking can be defined as "covering local problems, reporting local news, doing local programming, and providing an outlet for local voices" (Napoli 2001). Localism refers to the obligation of a communication policy to meet the needs and interests of the local community.

Zooming out of Indonesia, the early international history of taking localism principles into account in the making of communication policy began in the late 1790 when the Congress of the United States subsidized newspaper media. This program charged differential rates for publications based on each media's geographical reach. It was an effort to protect small local newspapers from the unhealthy competition with more extemsive metropolitan publications. In the end, this policy caused great controversy, mostly refusals to implement this policy. The refusing parties reasoned that it was all for public needs and the necessity to disseminate information as widely as possible. In the end, many parties kept insisting on sticking to the single tariff policy as well as removing the differential tariff policy (Napoli 2001).

In the context of television media regulation, the principle of localism initially appeared in the United States through the order to provide opportunities for local communities to each receive a television license, regardless of their actual financial capacity. At that time, the Federal Communications Commission (FCC) focused on ensuring that, at least, every city has one television station.

Table 1. The FCC's Special Allocation Priorities (Federal Communications Commission, 1952)

\begin{tabular}{cl}
\hline Priority 1 & To provide at least one television service in each state. \\
\hline Priority 2 & To provide at least one television broadcast station for each community. \\
\hline Priority 3 & To provide a choice for the public of at least two television services in each state. \\
\hline Priority 4 & To provide at least two television broadcast stations for each community. \\
\hline Priority 5 & $\begin{array}{l}\text { Channels which are not determined based on priorities } 1 \text { to } 4 \text { above will be given to various } \\
\text { communities depending on the population size of each community, the geographical location of } \\
\text { the community, and the number of television services available to that community provided by } \\
\text { television services located in other communities. }\end{array}$ \\
\hline
\end{tabular}

As a result of the priority allocations, every community, even the smallest ones, received a television license. Afterward, both radio and television broadcasting were developed under a regulatory structure oriented to maximize local broadcasting autonomy as an action to encourage national network development (Napoli 2001).

The link between localism and public interest becomes clearer when the FCC issued a policy related to broadcasting obligations in the public interest, including the need to broadcast local programs directly. The main purpose of this policy was to involve local programmers in broadcasting. However the main problem was the ambiguity and inconsistency about what can be called a 'local program' (Juditha 2015). 


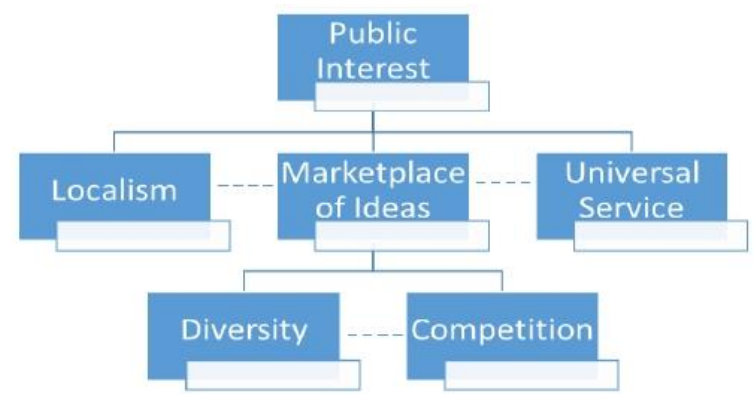

Figure 1. The relationship of basic principles of a communication policy (Napoli, 2001)

The above principles have survived for decades as important concepts in communication policymaking. They are considered as justification points in the formulation of communication policy decisions. What is prone to becoming a problem is the misinterpretation and misapplication of each principle (Aritonang 2013). A number of cases, where conflicting interpretations sourced from clashing principles occured, have been the subject of many years of debate.

Each principle has unique properties able to influence communication regulation. These principles will then produce influences on the potential of the communications industry for broad social and political effects. The concepts originating from each of these principles shape a complex and diverse collection of concepts. The inter-concept relationships reflect different yet interrelated values and policy directions (Napoli and Seaton 2006). Therefore, the use of the above principles as guidelines in the formulation of communication policies poses significant challenges for policymakers, both from a conceptual and methodological point of view.

The importance of localism in society is to raise awareness of local values as a discourse for creative thought and inspiration. The products of modern culture (cultures from outside Indonesia) can be said to have succeeded in diluting and dismissing local values that previously existed in society. However modern culture is undoubtedly inevitable and gradually reduces local values in society (Nahak 2019). If localism is then considered urgent as a way of thinking upon this situation, then a new challenge would arise. The challenge would be on how modern culture can be adapted and transformed into local or regional contexts so that a region would not lose its original identity. In that case, each region should be involved in making decisions that affect them (Ercan and Hendriks 2013).

Identity, from a cultural perspective, is the cultural values represented by society in the practices of everyday life (Ashmore, Jussim, and Wilder 2001). The perspective on identity cannot be separated from the historical and cultural contexts that had framed the life journey of a society. Identity serves as a guideline, direction, and self-control future circumstances. Thus, relating this to the context of the state, national identity is a characteristic possessed by a nation that is different from other nations. The national identity of the Indonesian people refers to 'the pluralistic nation'. This plurality is composed of various elements forming this national identity consists of a spectrum of diversity (Latra 2017).

1) Ethnic group

Indonesia is a nation that owns a vast range of ethnic groups and tribes, with no less than 714 national dialects.

2) Religion

There are various kinds of religions adhered to by Indonesian people as a religious community. Islam, Christianity, Catholicism, Buddhism, an Confucianism are religions which are mostly adhered to by the people of Indonesia.

3) Culture

Culture means a way of life developed and shared by a group of people and passed down from generation to generation. With regard to Indonesia's vast territory as an archipelagic country, a vibrant cultural diversity was also developed.

4) Language

Language is a supporting element of national identity as a symbol formed by the sound elements of human speech and serves as a means of interacting with others. There are approximately 1,000 regional languages in the country of Indonesia.

5) Archipelago

The vast territory and archipelago is a natural wealth that geographically belongs to Indonesia. 
6) Pancasila ideology

Pancasila functions as the ideology and basis of the Indonesian state.

In the end, this plurality produced pluralistic and multiculturalistic concepts in the life of Indonesian society. This concept is the main factor in the birth of the Indonesian motto, "Bhinneka Tunggal Ika” ('Unity in Diversity') (Imam Farisi 2014). It serves as a motivation to live together as a nation over a vibrant diversity. This motto has three characteristics (Baidillah 2010). The first is the absence of sectarian and exclusive nature. It means that there is no justification when one feels the most righteous or feels greater and better among others, causing an unwillingness to acknowledge the dignity of others. Second, it is informal, which means having mutual trust and respect in the creation of harmonious life. Lastly, it is convergent, which means that the differences in diversity are not to be negatively exaggerated, but rather to encourage society to find common grounds in the form of mutual agreement.

In short, the multiculturality makes Indonesia a gathering ground for a variety of cultures, ethnicities, values, norms, and understandings, which are always possible to differ from one another (Abazov 2007). In making policies that is expected to apply broadly to this diverse society, the localism principle must be made one of the top priorities. Since the localism principle requires clear and mutually agreed interpretation, it would be useful in policymaking and policy analysis. Surely, the aim is to formulate a policy that contains clear and consistent evaluative and substantive standards.

If the principle is not properly considered when a policy is ratified, it would generate a great possibility to produce opposing political arguments and arbitrary actions in its implementation. Differences in interpretation and emphasis on different degrees are generally the cause of the failure of an effective policy implementation in a multicultural society (Sherlock 2008).

The United States is renowned for its permissive and freedom-upholding culture. This is actually inseparable from the states' history. In the early days, the US enacted an "open door" policy for immigrants from all over the world to come and be welcome to settle down. The government then asked the immigrants who decided to stay to keep and practice their original culture while living in the United States (DeTocqueville 2009).

The people of the US realized that they do not have a single uniform indigenous culture passed down for generations. On the other hand, the cultural diversity gained from the immigrants eventually formed this superpower as a multicultural country. Although there are various cultural forms within the states, they have the country and cowboy culture, which became one of their trademark symbols and characteristics. Americans appreciate the cultural differences that are created. Caste, religion, and cultural diversity are not obstacles in their development. The ethic "trying to be better" is the living of the social life of the state (Fiorina et al. 2000).

The vast and relatively heterogeneous region makes each state in the US owns a culture that tends to be different from other states (Vargas and Kemmelmeier 2013). Regulations on pornography that are applied in this country are also determined differently on the basis of these considerations. An example enthusiast the difficulty of finding pornographic media in very conservative states such as Utah. However in other states like San Francisco, it is the opposite. Nonetheless, there is still an allstate standard called the 'community standard.'

The law-making in the US is guarded by the United States Department of Justice (DOJ) (Ercan and Hendriks 2013). It is a cabinet department in the government assigned to uphold the law, defend the interests of the people according to law, as well as to ensure justice and fair administration for all American society. It is this cabinet that functions to set community standards derived from different and widely various state regulations.

Pornography in the United States is defined as material(s) that contain sexual contents with the purpose of stimulating the audience sexually, obscenity included. The regulation on pornography in the states focuses on the distribution of pornographic and child pornographic content, shifting from the issue of essence to the problem of distribution and consumption (Miller et al. 2008). In the Child Obscenity and Pornography Prevention Act of 2002, it is stated very clearly about the prohibition of involving minors in obscene or pornographic activities.

In addition, the Child Abduction Prevention Act (CAPA) was formed in 1996 with the aim of enforcing tighter regulatory materials on child pornography (Fass 1997). CAPA is one of the legal products of a unified regulation called The Uniform Child Abduction Prevention Act (UCAPA) 
created by the National Conference of Commissioners on Uniform State Laws in 2006. It was then adopted by all states in the US with various adjustments according to local conditions .

In terms of distribution, in Kansas, pornographic material must be arranged in such a way in the blinder racks, so that two-thirds of the cover cannot be seen free. Whereas in the more stringent Virginia, it is required to make an adult-only counter to place pornographic products. Children are prohibited from entering the counter.

In the US, pornography products are divided into three categories, namely $\mathrm{X}, \mathrm{XX}$, and XXX. Category $\mathrm{X}$ is the category for products that contain mild visualizations or depictions of sexuality and nudity. The products do not depict sexual relationship explicitly, for example, kissing scenes. In the XX category (also called 'softcore'), pornography products contain bolder visualizations of sexual relations and scenes but not detailed. While in the XXX (or the 'hardcore') category, pornographic products contain clear and detailed visualization of sexual relations and scenes. The more $\mathrm{X}$ there is, the more restricted the distribution process and consumption are.

Exceptions to the explicit use of pornography are also regulated. For example, is the California Penal Code of the state of California. Mentioned in Articles 311.2 (b) and 311.3 (c) are exceptions of the use of pornography for the purpose of law enforcement, conducting investigations of violations of the law, medical interests, research or legal education, and other matters that are legal according to law to commit sexual intercourse.

Turkey is another large country in the Eurasian region whose territory extends from the Anatolian Peninsula in Southwest Asia to the Balkan region in Eastern Europe. Turkey is said to be a transcontinental country. The geographical position of Turkey makes the culture very rich with diverse elements derived from various pre-existing cultures brought together in old countries within the Eurasian region. The cultures that now reside in Turkey are multi-ethnic and multi-religious (Pultar 2013).

At its beginning, the government of Turkey carried out a process of modernization and the creation of cultural identity through the pouring of art resources such as paintings, carvings, and architecture. Turkey can be said to be the only country that has strikingly contrasted eastern and western cultures with a lot of mixing and compromise between the two. These two cultures are traditional Muslim culture in Anatolia and Istanbul's cosmopolitan modernity with hints of the wider Western world. It turned out that, rather than resulting in cultural uniformity, the mixing and compromising between the two cultures produced a "gray" culture instead (Abazov 2007). Pornography in Turkey is regulated in the Penal Code of Turkey. Part 7 of Chapter III, Offences Against the Public, Article 226 Paragraph (1) states the prohibition in pornography, written as follows (Government of Turkey 2016).

"Any person who:

a) gives to a child obscene written or audio-visual material; or who reads or induces another to read such material to a child or makes a child watch or listen to such material;

b) makes public the content of such material in a place accessible or visible to a child, or who exhibits such material in a visible manner or who reads or talks about such material, or who induces another to read or talk about such material to a child;

c) offers such materials for sale or rent in such a manner as to reveal the content of that material;

d) offers for sale, sells or rents such materials, in any place other than a specified, or of sale;

e) gives or distributes such materials along with the sale of other products or services as a free supplement; or advertises such products shall be sentenced to a penalty of imprisonment for a term of six months to two years and a judicial fine."

From the above quotation, it can be seen that Turkey's regulation of pornography focuses on child pornography, more profoundly mentioned in other verses of the same article.

Similar to US regulation, which provides exceptions to the use of products containing pornographic contents, Turkey also enacts exception in Article 227 of the Penal Code of Turkey, Part 7. This exception is intended for the benefit of art, science, and obscenity prevention literature for children. This explicit explanation of the exception also sharpens the definition of 'obscenity' for Turkey.

Ambiguity can be defined as to have meaning more than one (that sometimes it causes doubt, obscurity, obscurity); double meaning; taxa. An ambiguous matter (a sentence) means it is something 
that has more than one normal interpretation (Crane 1981). Ambiguity is generally different from obscurity. In ambiguity, specific and different interpretations may arise, while obscure information emerges in the difficulty of producing any interpretation at the desired level of specification. Certainly, ambiguity is very much avoided in the formulation of a policy, especially if the policy is going to be widely applied to a community with great diversity, such as the Indonesia state. Even in the same community environment, a single case or matter can bring up different perspectives about it, all the more if it occurs in a diverse social environment (Mufid 2009).

Bali and Papua are regions in which the society explicitly rejects the enactment of Law No. 44 of 2008 on Pornography. The assertiveness of The Balinese people is shown through a rejection letter coming from the Governor and the Regional Representative Council (DPRD) of Bali, which was submitted to the central government. This rejection was made because the Law on Pornography is considered to have threatened the Unitary State of the Republic of Indonesia (NKRI) and contradicted the 1945 Constitution for discriminating partial citizens of the nation (Kompas 2008a). While in Papua, the Chairperson of the West Papua Regional Representative Council, urged the central government to revoke the Law on Pornography. It went to the extent of the threat to separate West Papua from the Unitary State of the Republic of Indonesia if the request was not heeded (Tempo 2008). The enactment of the law was considered a menace to Papuan culture and is only beneficial for certain religious interests. The ratification of the Act was also considered hasty and without sufficient socialization.

In the Law No. 12 of 2011, it is stated in Article 2 that, "Pancasila is the source of all sources of state law" and in Article 3 that, "The 1945 Constitution of the Republic of Indonesia is the source of all sources of state law" (Ministry of Law and Human Rights of Indonesia 2011). This confirms that every law and regulation in Indonesia must not in conflict with Pancasila and the 1945 Constitution. However, the ratified Law on Pornography was considered by many to conflict with both Pancasila and the 1945 Constitution. The third principle in Pancasila, "Persatuan Indonesia" (literally translates to 'A unified Indonesia'), as well as both Article 1 Section (3) and Article 28D Section (1) of the 1945 Constitution concerning legal certainty, are a few fundamental points deemed to have been violated by the Law on Pornography.

The establishment of legislation is also discussed in Chapter II Article 5 of the constitution, which consists of certain principles: 1) Clarity of objectives; 2) Appropriate institutional or official formation; 3) Conformity between type, hierarchy, and content material; 4) Implementation certainty; 5) Usability and efficacy; 6) Clarity of formulation; and 7) Openness. The compilation of Law No. 44 of 2008 on Pornography is considered to violate several regulated principles as described below.

1) Clarity of objectives

The purpose of the compilation of the Law on Pornography, which in general is to create and maintain an ethical and orderly social life, as well as upholding human dignity, is considered difficult to measure because anything related to ethics, personality, and values of the 'belief in the one and only God' (as it is the first principle of Pancasila) and human dignity are too precarious to be regulated normatively with statutory rules.

2) Appropriate institutional or official formation

The eligibility of the "values and morals reference" picked and used as basis substance is questioned. It has the potential to cause controversy in terms of interpretation and application of legal sanctions due to differences in values and moral views within the reality of the society. This raises the question of whether this regulation would truly be applicable and brings clear benefits by being implemented.

3) Clarity of formulation

The boundaries of the basic of understanding and definition in the law are considered to be very vague and contain a high degree of obscurity. Since this unclear definition later meets the rich spectrum of Indonesian values and norms, the adoption of the law will also be applied variously by each culture. The credibility of certain parties who are then given the authority to define or interpret the formulation of this Act will always be in question.

4) Openness

This principle requires that the formation of laws and regulations, starting from planning, preparation, and discussion are transparent and open so that the whole society can provide inputs as widely as possible. Various regions have been rallying and rejecting before and after the ratification of the law. One of the issues raised by these actions is the perceived lack of aspiration hearings during the drafting process of the law. 
The content(s) of any Indonesian legislation is also regulated in Law No. 12 of 2011: it must reflect the principles of protection, humanity, nationality, kinship, recollection as part of the archipelago, unity in diversity, justice, equality before law, and government, order and legal certainty and/or balance, harmony, and conformity. The Law on Pornography is perceived as not reflecting the nationality, the archipelago values, unity in diversity, justice, legal certainty, and the balance, harmony, and conformity that should be considered firstly in its preparation.

Continuing pros and cons throughout the formulation to the enactment of the Law on Pornography are clearly visible in media, discussion forums, socialization forums, as well as various demonstrations and cultural marches. Even the final discussion of this particular Act at the House of Representatives (DPR) actually did not go smoothly with the walk out of the Indonesian Democratic Party of Struggle (PDI-P) faction and the Prosperous Peace Party (PDS) faction during the plenary meeting of its ratification (Liputan6 2008).

Ambiguity and legal uncertainty were the main problems and still are the main factors of more recent rejections in various circles and regions (Apriadi 2010). In essence, if a statutory regulation contains a high degree of uncertainty in the definition contained in its General Provisions, it will always affect its derivative articles. Wherefore, the definition contains the main idea that perennially underlies and forms the formulation basis of all subsequent articles (Laksana and Suratman 2014). In other words, the derivative articles certainly cannot be appropriately formulated and implemented when the main idea itself is ambiguous or uncertain.

How the rejection of Indonesian Law on Pornography, from the beginning of the formulation to its ratification, takes various forms from street demonstrations to cultural marches, is certainly not without cause. Some articles in this law are deemed incompatible with the reality of Indonesian society with its multicultural and plural national identity. Ambiguity and legal uncertainty are also contained in the pornography law, which makes many people question its implementation. Article 1 Section (1) states the definition of pornography as follows.

"Pornography is a picture, sketch, illustration, photo, text, voice, sound, moving picture, animation, cartoon, conversation, gestures, or other forms of messages through various forms of communication media and/or public display, which contains obscenity or sexual exploitation that violates the norms of decency in society.", (Ministry of Law and Human Rights of Indonesia 2008)

The phrase "which contains sexual obscenity or exploitation that violates the norms of decency in society" ties this definition with the customary and religious norms that apply to society. As a result, the application of this pornography law should be expected to affect differently to each cultural society. However, the beam to the controversy of this definition, which is the ambiguity, is also present in this very phrase.

The broad, unclear, and multi-interpretive definition of the concept 'pornography' could threaten the human rights of individuals, groups, or even communities in Indonesia. Indonesian pluralistic and multicultural national identity could result in the differences of perspective, custom, and procedure to see whether an action can be included in pornography or not. This obscurity of the definition of pornography is actually threatening to eliminate the basic principles of nationalism and the diversity of Indonesia.

As an outcome, there rises an assumption that this law probably aims to unite views on morality and decency from a narrow, shallow, and one-sourced viewpoint. How it seemingly came from a particular perspective is seen by a part of the public as an effort to eliminate the essence of diversity, plurality, and difference that exists in the nation (Firdaus 2010). This law is also considered not to provide protection to arts, culture, customs, and religious rituals that have long been existing. It is even considered violating a series of human rights and is discriminatory against certain groups that have been guaranteed in the 1945 Constitution.

Some of the other phrases in this Law on Pornography also have unclear definitions. Among them are the phrases 'in public' and 'impress nudity.' There are no further written details of the phrase 'in public' in the explanation section of this law. This lack of clarity eventually supported the case of a suspect determination in January 2018. The one determined as the suspect was one of several men arrested in a room in Cipanas Villa. The man was considered to have participated in a same-sex party and was the one who provided the facilities. The police assumed that conducting sexual acts in a room within a villa can be considered "in public," although many might disagree.

The problem with the phrase 'impressing nudity' lies in its explanation in Article 4 Section (1) Letter d, which reads, "What is meant by 'impressing nudity' is a condition of someone who uses 
body coverings, but still reveals genitals explicitly." Is someone who uses body coverings but still looks clearly curved included in the subject referred to by this phrase? Referring to medical science, the phrase 'still expresses genitals explicitly' can mean the prohibition to show the penis and/or vagina, but does not apply to other body parts. What about women's breasts? Is showing breasts not included in the prohibitions in this article? The gist of this explanation will be directly related to the implementation of other articles relating to violations of Article 4 Section (1), which then refers to criminal sanctions. The unclear definition of this section creates legal uncertainty against violators of this pornography policy.

Opportunities for the public to participate in the prevention and production, distribution, and use of pornography are also regulated in Article 20 and Article 21. Differences in understanding the term 'pornography' will also influence the implementation of these articles. Many worried about how some people would not hesitate to take judgment into their own hands and carry out acts of violence, conduct raids (sweeping), and raids on other minor communities, with pornography as their reasoning. Minority communities are vulnerable people who are considered inferior. They usually have small numbers and have different cultures and understandings of values and norms with the majority community in the area. If such a thing happens, it might trigger communalism and division in society.

The researcher is trying to compare Indonesia with two other countries discussed earlier. What the US and Indonesia have in common is the diversity of citizens and the wide state(s) area. However, the US does not apply a single same rule for all its states. The government realizes that all states, each one with another, have various gaps and differences. Each state has its own culture and outlook that cannot be compared to other states, including viewing and regulating pornography. The drafting of regulations on pornography is entrusted to the respective state governments. Regulations are then made and guarded by the DOJ by setting certain community standards.

Turkey has similarities with Indonesia in terms of diverse cultural communities influenced by the geographical location as well as the history of the country. Turkey has strikingly contrasted eastern and western cultures which are characterized by a lot of mixing and compromise between the two. These two cultures are traditional Muslim cultures from Anatolia colliding with the cosmopolitan modernity of Istanbul and the wider Western world. Mixing and compromising these two cultures then did not produce a uniform culture, but rather produced a "gray" culture.

In the Penal Code of Turkey, Chapter III Part 7, which is a regulation governing obscenity and pornography, Turkey does not clearly define obscenity and pornography. However the details contained in its derivative rules clearly show the country's focus on the prohibition of involving minors in pornography or child pornography. All forms of prohibition in obscenity are regulated in Article 226, which also provides severe criminal sanctions for violators (Government of Turkey 2016).

The similarity between the US and Turkey in regulating pornography is their focus on the distribution of pornographic content and child pornography. The two countries shifted the issue from the essence of the staple of pornography to the problem of distribution and consumption. Pornographic content is strictly regulated in its distribution, especially to avoid its use by minors. The two countries also clearly write exceptions to the use of pornographic products. They generally allow the use of pornography in the fields of law, education, and arts. There exist many points from these two countries, in the aspect of the diversity of society culture, that is similar to Indonesia. These similarities can be used by the Indonesian government as exemplifications to make similar pornographic regulations so as to create an effective policy in its implementation.

Legislation should take into account the effectiveness of its implementation in the community philosophically, juridically, and sociologically. Indonesian Law on Pornography clearly cannot be implemented properly because it clashes with the Indonesian people's cultural and custom diversity (Constitutional Court of Indonesia 2009). The desired fairness to every citizen is not reflected in the implementation of this law. Some people from regions even considered it as a law that opens unwanted opportunities to stigmatize some groups and discriminate against certain regions or cultures.

This anti-pornography law also has the potential to be ineffective and unsuccessful in its implementation. Even further, it is considered to threaten the life of the nation and state since it leads to disintegration. Disintegration is defined as the disappearance of the state of unity and wholenes and later causes division. The urgency of this law is continued to be questioned. It is often considered as not-that-necessary and not having clear benefits for the life of the nation and state society. 


\section{CONCLUSION}

The localism principle should be one of the main guidelines in the formulation of a policy in a multicultural country like Indonesia. The aim is to continue to uphold national identity with its slogan, 'unity in diversity,' which has long motivated the nation to live together as one regarding the great diversity. Differences in views, which are the main problem in the implementation of the Law on Pornography, were caused by the very situation in which the localism principle was not used as a guideline in its formulation.

As a multicultural country, it is the everyday consequence for Indonesian people to have different perspectives on nearly every matter. That is all the more demand for as much clarity in a formulation of a policy as it is possible. The clarity of the formulation was probably the most discussed topic in the making of this Law on Pornography. However in its definition, this law still contains ambiguous words or sentences, which are unclear and difficult to be detailed in the explanation of subsequent articles.

Ambiguity and obscurity are mainly within the Article 1 Section (1) regarding the definition of pornography. The written definition is considered too broad, unclear, and open for multiinterpretative. A plentiful amount of debates have been held to discuss and question the interpretation of this article, especially among artists and humanists. The definition contained does not elaborate a clear restriction or limitation on the term 'pornography.'

One of the "conclusions" of the controversy is the assumption that this policy probably aims to eliminate the principles of nationality and diversity of Indonesia by uniting views on morality from a narrow, shallow, and single-sourced perspective. The essence of Bhinneka (diversity), pluralism, and difference that has been valued and respected by Indonesian people are threatened to disappear.

The ambiguity in Article 1 Section (1), which is supposed to provide basis substance for the implementation of other articles, further makes other related articles ambiguous and obscure. The widening of this ambiguity would subsequently inflict legal uncertainty on the criminal sanctions regulated in Article 29 to Article 38. Certainly, it is terribly undesirable and dangerous to prosecute someone based on policies which are multi-interpretive and can be understood in a variety of ways.

High ambiguity and legal uncertainty in Article 1 Section (1), Article 4, and articles on legal actions for violations of the Law on Pornography are able to threaten the national unity that has long been nurtured by mutual respect between ethnic groups, religions, culture, language, and more. This threatening milieu is an indicator that the formulation of the Law No. 44 of 2008 on Pornography had ignored the principle of localism as a guideline for its formulation.

The government should take action and make a change to ensure the protection of the existing cultural differences and to avoid national disunity. This can be done by entrusting the establishment and implementation of pornographic regulations to each local government by taking an example from the United States. Restrictions on pornography products should also focus on the distribution and child pornography as applied in Turkey. The whole pornography regulations should shift its primary focus into the problems of distribution and consumption.

The researcher suggests a revision to the Article 1 Section (1) regarding the definition of pornography. The definition needs a much clearer description and boundaries, as well as taking local wisdoms into account. This definition should also not be used as a normative prohibitio for the uniqueness of ethics, personality, and values of spirituality depend on each culture, religion, and norms held by individuals in society. Exceptions to the use of pornography products should also be written in the body of the law in the implementation of the law.

\section{REFERENCES}

Abazov, Rafis. 2007. Culture and Customs of the Central Asian Republics. London: Greenwood. Apriadi, Indra. 2010. IMPLEMENTASI REGULASI PORNOGRAFI DI INDONESIA. Jakarta: Ministry of Law and Human Rights of Indonesia.

Aritonang, Agusly Irawan. 2013. "Kebijakan Komunikasi Di Indonesia: Gambaran Implementasi UU No. 14 Tahun 2008 Tentang Keterbukaan Informasi Publik.” Jurnal Komunikasi 1(2):26186.

Ashmore, Richard D., Lee Jussim, and David Wilder. 2001. Social Identity, Intergroup Conflict, and Conflict Reduction, Volume 3. Vol. 3. Oxford University Press. 
Baidillah, Aan. 2010. Sikap Positif Terhadap Pancasila, UUD, NKRI, Bhinneka Tunggal Ika. Jakarta: Ombak.

Constitutional Court of Indonesia. 2009. Putusan Nomor 10-17-23/PUU-VII/2009.

Cooper, Harris M. 1989. Integrating Research: A Guide For Literature Reviews. Newbury Park: Sage.

Crane, Ben L. 1981. An Introduction To Linguistics. Boston: Little Brown.

DeTocqueville, Alexis. 2009. Democracy In America. Vol. 4. edited by E. Nolla. Liberty Fund, Inc.

Ercan, Selen A., and Carolyn M. Hendriks. 2013. "The Democratic Challenges and Potential of Localism: Insights From Deliberative Democracy.” Policy Studies 34(4):422-40.

Fass, Paula S. 1997. Kidnapped: Child Abductions in America. New York: Oxford UniversityPress.

Fiorina, Morris, Paul Peterson, Bertram Johnson, and William Mayer. 2000. The New American Democracy. London: Longman.

Firdaus, Syam. 2010. Analisis Dan Evaluasi Undang-Undang No 44.Tahun 2008 Tentang Pornografi. Government of Turkey. 2016. Penal Code of Turkey.

Imam Farisi, Mohammad. 2014. "Bhinneka Tunggal Ika (Unity in Diversity): From Dynastic Policy to Classroom Practice.” Journal of Social Science Education 13(1):46-61.

Juditha, Christiany. 2015. "Televisi Lokal Dan Konten Kearifan Lokal (Studi Kasus Di Sindo TV Kendari.” Jurnal Penelitian Komunikasi Dan Pembangunan 16(1):49-64.

Kompas. 2008a. "Rakyat Bali Tegas Tolak UU Pornografi." Kompas Online.

Kompas. 2008b. "RUU Pornografi Dinilai Cacat Oleh Banyak Pihak." Kompas Online.

Laksana, Andri Winjaya, and Suratman. 2014. "Analisis Yuridis Pendidikan Tindak Pidana Pornografi Berdasarkan Undang-Undang Nomor 44 Tahun 2008 Di Era Digitalisasi.” Jurnal Pembaharuan Hukum I(2):169-77.

Latra, I. Wayan. 2017. "Identitas Nasional Sebagai Salah Satu Determinan Dalam Pembangunan Bangsa Dan Karakter." Udayana University.

Liputan6. 2008. "PDIP-PDS Walk Out.” Liputan6 Online.

Miller, J. Mitchell, Megan Kurlycheck, J. Andrew Hansen, and Kristine Wilson. 2008. "Examining Child Abduction by Offender Type Patterns." Justice Quarterly 25(3):523-43.

Ministry of Law and Human Rights of Indonesia. 2008. Undang-Undang No 44 Thn 2008 Tentang Pornografi.

Ministry of Law and Human Rights of Indonesia. 2011. Undang-Undang Nomor 12 Tahun 2011 Tentang Pembentukan Peraturan Perundang-Undangan. Vol. 11.

Mufid, Muhamad. 2009. Etika Dan Filsafat Komunikasi. Prenadamedia Group.

Mustika, I. Made Adhy. 2016. "UU No. 44 Tahun 2008 Tentang Pornografi Ditinjau Dari Perspektif Politik Hukum.” Jurnal Magister Hukum Udayana 5(3):459-66.

Nahak, Hildigardis M. I. 2019. "Upaya Melestarikan Budayaindonesiadi Era Globalisasi." Jurnal Sosiologi Nusantara 5(1):65-76.

Napoli, Philip M. 2001. "The Localism Principle in Communications Policymaking and Policy Analysis: Ambiguity, Inconsistency, and Empirical Neglect." Policy Studies Journal 29(3):372-87.

Napoli, Philip M., and Michelle Seaton. 2006. "Necessary Knowledge for Communications Policy: Information Asymmetries and Commercial Data Access and Usage in the Policymaking Process." Federal Communications Law Journal 59:295-330.

Pultar, Gonul. 2013. "Cultural Studies in Turkey: The State of the Art." Culture Unbound 5(1):43-71.

Sherlock, Stephen. 2008. "Parties and Decision-Making in the Indonesian Parliament: A Case Study of RUU APP, the Anti-Pornography Bill.” Australian Journal of Asian Law 10(2):159.

Sukmadinata, Nana Syaodih. 2009. Metode Penelitian Pendidikan. Bandung: PT. Remaja Rosdakarya.

Tempo. 2008. "Tolak Undang-Undang Pornografi, Papua Barat Ancam Pisah Dari NKRI.” Nasional Tempo Online.

Torraco, Richard J. 2005. "Writing Integrative Literature Reviews: Guidelines And Examples." Human Resource Development Review 4(1):356-67.

Vargas, Jose H., and Markus Kemmelmeier. 2013. "Ethnicity and Contemporary American Culture: A Meta-Analytic Investigation of Horizontal-Vertical Individualism-Collectivism.” Journal of Cross-Cultural Psychology 44(2):195-222. 